Review

\title{
Parasite Cystatin: Immunomodulatory Molecule with Therapeutic Activity against Immune Mediated Disorders
}

\author{
Vishal Khatri *(D), Nikhil Chauhan and Ramaswamy Kalyanasundaram $(\mathbb{D}$ \\ Department of Biomedical Sciences, University of Illinois College of Medicine, Rockford, IL 61107, USA; \\ nikhilc3@uic.edu (N.C.); ramswamy@uic.edu (R.K.) \\ * Correspondence: vkkhatr4@uic.edu; Tel.: +1-815-395-5695
}

Received: 11 May 2020; Accepted: 28 May 2020; Published: 30 May 2020

check for updates

\begin{abstract}
The use of parasites or their products for treating chronic inflammation associated diseases (CIADs) has generated significant attention recently. Findings from basic and clinical research have provided valuable information on strengthening the notion that parasites' molecules can be developed as biotherapeutic agents. Completion of the genome, secreotome, and proteome of the parasites has provided an excellent platform for screening and identifying several host immunomodulatory molecules from the parasites and evaluate their therapeutic potential for CIADs. One of the widely studied host immunomodulatory molecules of the parasites is the cysteine protease inhibitor (cystatin), which is primarily secreted by the parasites to evade host immune responses. In this review, we have attempted to summarize the findings to date on the use of helminth parasite-derived cystatin as a therapeutic agent against CIADs. Although several studies suggest a role for alternatively activated macrophages, other regulatory cells, and immunosuppressive molecules, in this immunoregulatory activity of the parasite-derived cystatin, there is still no clear demonstration as to how cystatin induces its anti-inflammatory effect in suppressing CIADs.
\end{abstract}

Keywords: helminth therapy; cystatin; chronic inflammatory disorders; autoimmune disorders; biotherapeutic

\section{Introduction}

Incidences of chronic inflammation associated diseases (CIADs) are surging worldwide [1]. CIADs include, but not limited to, inflammatory bowel disease, multiple sclerosis, rheumatoid arthritis, and allergies. The mainstream therapy for CIADs is not advancing enough. In addition, such therapy is suppressive with limited efficacy and short-term effects, may lead to cancer or other opportunistic infections, and is often costly and time-consuming [2,3]. Meanwhile, alternative therapies for CIADs are gaining popularity [4]. One such approach is the use of helminths, or their products to treat CIADs. The therapeutic strategy of using helminths to subvert aggressive inflammatory immune responses in CIADs is known as helminth therapy (HT) [5]. Helminths are a group of parasitic organisms that infect humans. They are large multicellular organisms comprising nematodes, cestodes, and trematodes. Over one-sixth of the world's population is infected with parasitic helminths $[6,7]$. The proposition of using HT for treating CIADs emerged in the early 1990s [5,8]. Developed countries with improved hygiene, and deworming programs, often report an increase in the incidences of CIADs, whereas, underdeveloped countries where parasitic infection is greater have fewer cases of CIADs $[9,10]$. Theories, such as 'hygiene hypothesis' and later revised as 'old friends' hypothesis', proposed the symbiotic relationship between helminths and human [11-13]. Thus, an inverse relationship exists between childhood exposure to moderate helminth infections and the emergence of allergies later 
in life [12,13]. Moderate exposure to helminths was found to be beneficial to the host in reducing CIADs symptoms [10]. Subsequently, supporting evidences came from a plethora of studies, where a positive association between exposure to helminths and reduced occurrence of CIADs was clearly demonstrated $[5,14,15]$.

The human immune system is a pool of several concatenated components involving complex mechanisms. Helminths have evolved several survival strategies to evade the human immune system, which include secreting several immunomodulatory molecules that can manipulate host inflammatory immune responses [16]. The immunosuppression induced by helminth parasites has been exploited by several laboratories around the world to suppress inflammation, allergies, and severe immune-mediated reactions $[17,18]$. Initial studies utilized live or attenuated parasites or their eggs to treat immune-mediated disorders [17]. However, using live parasites (including their eggs) had several aesthetic concerns [19]; (1) parasites must elicit minimum pathology in the human, especially live parasites in immuno-vulnerable patients (infants/elderly) or immunocompromised individuals could pose the risk of infection, (2) skewed immune response could expose the host to other opportunistic infections, (3) aberrant migration of the helminth parasites may cause problems, (4) the potential for worms to establish and reproduce if the infection is chronic, and (5) most importantly, ethical considerations associated with the use of live helminths. These drawbacks prevented further use of live helminth therapy. Immunologists started looking for molecules secreted by the parasites (excretory-secretory and soluble proteins) that have immunomodulatory activity. Soluble egg and worm proteins or excretory-secretory proteins from Schistosoma mansoni, Ancylostoma caninum, Anisakis, Trichuris suis, and Brugia malayi are shown to inhibit immune responses in experimental colitis, rheumatoid arthritis, multiple sclerosis, and type-1 diabetes [20-29]. Advances in the genomics and proteomics of helminth parasites identified several molecules secreted by the parasites that have significant host immunomodulatory activities [8]. Functional studies on these molecules demonstrated significant therapeutic potential against several CIADs $[4,30]$. Some of the molecules, such as ES-62, Fasciola hepatica FhCL1 (cathepsin L cysteine protease) and FhHDM (peptide with a cathelicidin-like C-terminal alpha helix), S. mansoni derived chemokine binding proteins, Sj16, Sm16, etc., have been shown to have modulatory effects on inflammation and autoimmunity [29]. In this review, we will focus on one such immunomodulatory molecule called Cystatin, which is secreted by certain helminth parasites and is believed to help the parasites evade the host immune responses and thus survive in a hostile environment [31]. Cystatin is a cysteine protease inhibitor that is most extensively studied for its immunomodulatory function in the host.

\section{Cystatins}

Cystatins are naturally occurring intracellular cysteine protease inhibitors that are extensively expressed across all living organisms, from protozoa to mammals. Cystatins are mostly localized in the endosomes and lysosomes [32], however, they can also be found in the nucleus, cytosol, cell membrane, or secreted from the cells [33]. Cystatins participate in many vital physiologic processes and interfere in the immune processes (antigen processing and presentation, migration of immune cells, activation of toll-like receptors, and cytokines secretion), wound healing, bone remodeling, osteogenesis and reabsorption, proprotein processing, and disease progression (such as cancer and inflammation) [34-37]. Furthermore, they also participate in regulating lysosomal cathepsins and in defense mechanisms against microbial and parasitic infections [31]. The key structural characteristics of cystatins are highly conserved. X-ray crystallographic studies of cystatins revealed three highly conserved regions forming a distinct wedge-shaped structure that blocks the active site of $\mathrm{C} 1$ cysteine proteases [38]. Some of the conserved structural elements include $\mathrm{N}$-terminal signal peptide, an approximately 100 amino acid domain, two disulfide bonds, a central glutamine-valine-glycine motif, and a C-terminal pro-trp hairpin loop (Figure 1). Some cystatins (human C, E, and F and all type-2 cystatins) also possess asparaginyl endopeptidase (AEP) inhibitory activity in addition to cysteine-protease inhibitory activity [31,38]. Based on the expression, localization, structural variations, and physiological roles, 
the three major families of cystatins include type- 1 or stefins (cystatins A and B), type-2 (cystatins C, E, and S), and type-3 or kininogens [33].

A

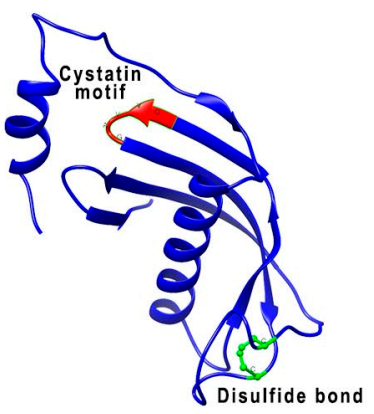

Type- 1 cystatin

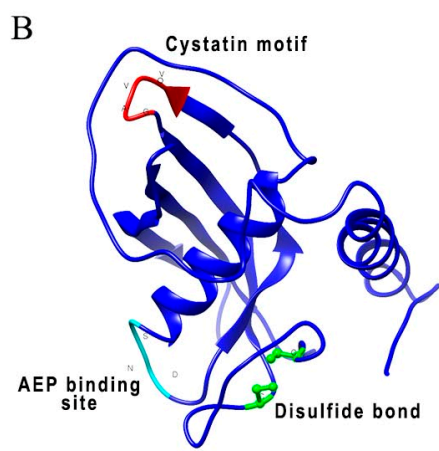

Type-2 cystatin

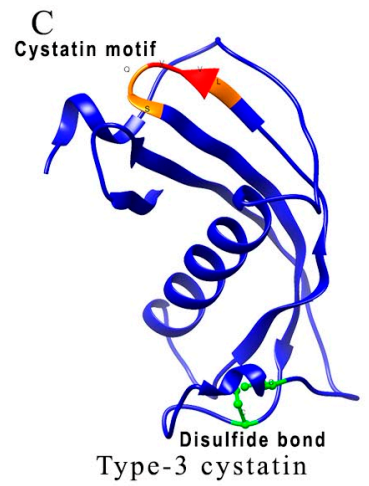

Type-3 cystatin

Figure 1. Comparison between different types of Brugia malayi cystatins. (A-C) 3D schematic representations of cystatin's protein structures show conserved sites, such as QVVAG (highlighted in red), asparaginyl endopeptidase (AEP) binding loop (highlighted in cyan), and position of cysteine residues involved in disulfide bonding (highlighted in green). The proposed AEP binding loop residues are present only in B. malayi CPI-2. In B. malayi CPI-3, conserved QVVAG sites are modified to LVVQS sites (modified residues are shown in orange). Accession number for protein sequences used in structural analysis are as follows: B. malayi CPI-1 (AAC47623.1); CPI-2 (AAB69857.1); CPI-3 (VIO99455.1). Molecular graphics and analyses performed with UCSF Chimera, developed by the Resource for Biocomputing, Visualization, and Informatics at the University of California, San Francisco, with support from NIH P41-GM103311 [39].

Type-1 cystatins, also known as stefins, are primarily intracellular proteins with a brief appearance in body fluids [40]. Stefins are about 100 amino acid residues long, not glycosylated, and lacks disulfide bonds (Figure 1A). Stefins are present in germinal centers of secondary lymphoid organs and follicular dendritic cells (DC) [41]. Stefins have regulatory potential for exogenous proteases [42]. They also play an important role in neonatal skin development and immune responses [43]. In the presence of stefin B, IFN- $\gamma$ activated mouse peritoneal cells showed enhanced release of nitric oxide (NO), suggesting a potential modulatory role of stefins on macrophages [44]. Mutations in the stefin B gene result in neurological dysfunction characterized as a form of epilepsy $[45,46]$. Stefin B deficiency led to the downregulation of IFN- $\gamma$ regulated genes in microglia and the resident tissue macrophages in the central nervous system of mice showing their involvement in innate immune responses [47,48].

Type- 2 cystatins are secreted as single-chain proteins of about 120 amino acids long and contain two conserved disulfide bridges and an N-terminal signal sequence (Figure 1B) [42]. There are seven different types of identified type-2 cystatins [42]. Cystatin $C$ is one of the most abundant type-2 cystatins expressed in human tissues [33]. Cystatin $C$ also has an additional AEP inhibitory segment located on the loop at the C-terminal end of the alpha-helix. Type-2 cystatin levels are high in body fluids acting as emergency inhibitors of redundant proteolytic activity outside cells [49] and have a diagnostic value for several diseases [50]. Cystatin C is particularly important in assessing kidney functions and is recommended by regulatory agencies for the evaluation of the glomerular filtration rate [51]. Serum levels of cystatin $C$ in association with serum creatinine, serve as a prognosis and/or diagnostic biomarker for assessing kidney function [52]. Type-2 cystatins are shown to take part in several immune-regulatory activities [42]. Cystatin C has been shown to strongly inhibit the cathepsin S and L activity and invariant chain (li) processing in DC [53]. Nematode cystatins also come under the category of type-2 cystatins. They are shown to inhibit cathepsins B, L, S, and AEP [40]. Nematode cystatins have also been involved in regulating antigen processing and presentation in antigen-presenting cells (APC), and subsequent downmodulation of host T-cell responses [40]. This review will focus on discussing the immunoregulatory and therapeutic capabilities of nematode cystatins. 
Type- 3 cystatins (kininogens) are the most complex cystatins consisting of three type 2 domains. Kininogens are about 350 amino acid residues long, mostly glycosylated, and consist of eight disulfide bonds (Figure 1C) [33]. Kininogens are secretory proteins and provide systemic protection against leaking endolysosomal cysteine peptidases. They are involved in both innate and adaptive immune responses [40,54].

\section{Parasite Cystatins as Immunomodulators}

Parasite cystatins, including other immunomodulatory molecules, are critically involved in the establishment of active parasitism in the hosts [31]. Amongst the different types of cystatins secreted by the parasites throughout their life stages, type 2 cystatins are known to significantly contribute towards immunosuppression in humans [31]. Cystatins are essentially produced by parasites to suppress host immune responses so that the parasite can survive in the host [55]. The mechanism by which parasite cystatins impairs host immune responses involves inhibition of antigen processing and presentation in APC, suppression of T cell proliferation, regulation of pattern recognition receptors, and receptor-mediated modulation of macrophages and dendritic cells by triggering the release of suppressive cytokines.

\subsection{Inhibition of Antigen Processing and Presentation}

Antigenic peptides are expressed on the surface of APC, such as macrophages and dendritic cells. Cysteine proteases present in the endosomal compartments play an essential functional role in this process of antigen processing and presentation by trimming and cutting of protein antigens and cleaving off the invariant chain (Figure 2) [56]. These degraded proteins undergo epitope selection and presentation on the cell surface in the context of MHC Class II [56]. This process of antigen presentation is normally regulated by various endogenous protease inhibitors, such as cystatins that act as inhibitors for endosomal cysteine proteases. Parasite cystatins are also shown to inhibit endosomal cysteine proteases, thereby modulating immune activation of host cells (Figure 2) [31,38,55,57]. Cystatins from different parasites are shown to possess papain inhibitory enzymatic activity in vitro [38,54,58-60]. This inhibitory activity of cystatins can also interfere with the Class II antigen presentation system in APC by efficiently blocking cathepsin activity. Blocking antigen degradation by cystatins leads to reduced MHC-II antigen presentation in APC. Onchocystatin from the Onchocerca parasite inhibits the purified protein derivative (PPD)-specific proliferation of APC in human PBMC cultures, suggesting interference of the antigen presentation by APCs induced with parasite cystatins [61]. Recombinant cystatin from Onchocerca volvulus, Ascaris lumbricoides, and Heligmosomoides polygyrus can reduce the surface expression of HLA-DR, CD40, and CD86 co-stimulatory molecules on human monocytes, which are critical for antigen presentation [61-64]. Downmodulation of HLA-DR and CD86 expression by the parasite cystatins suggest an alternative receptor-mediated effect of cystatin on APC. Recombinant tick cystatin and Trichinella spiralis cystatin also show similar modulatory effects on APC hampering antigen presentation and downregulation of surface expression of CD80 and CD86 [65-67].

Few parasite cystatins, such as CPI-2 from B. malayi filarial parasite, also possess an additional asparginyl endopeptidase (AEP) inhibitory site that may also interfere with the MHC Class II antigen processing in human APCs by inhibiting asparginyl endopeptidase [38]. AEP inhibitory sites are common in human cystatins but not in all nematode cystatins. This feature is probably acquired by certain nematodes during their co-evolution with humans. AEP are endo or lysosomal cysteine endopeptidase that play a key role in the maturation of toll-like receptors [58]. Thus, inhibiting AEP can block toll-like receptors' (LPS) mediated signaling pathways leading to reduced production of inflammatory cytokines and other co-stimulatory molecules [68]. 


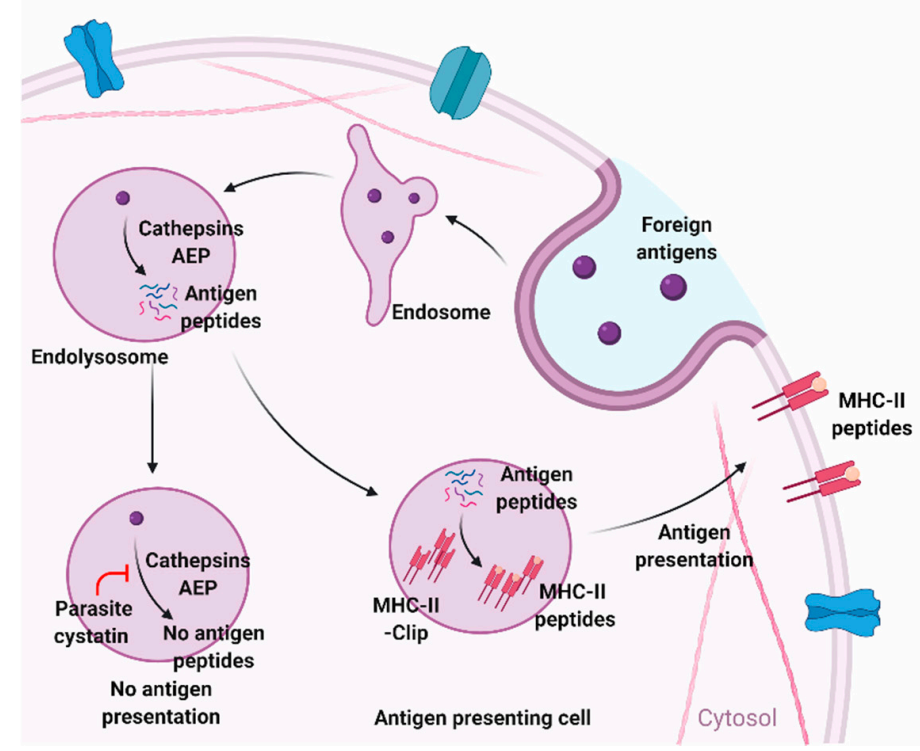

Figure 2. Modulation of antigen-presentation by parasite cystatins in antigen-presenting cells. Cysteine proteases and asparagine endopeptidase (AEP) degrades foreign antigens and present them on the surface of antigen-presenting cells (APC) as MHC-II-peptide complexes. Cystatin gets involved in this antigen degradation and presenting mechanism of APC by blocking cysteine proteases and AEP. Figure created using Biorender.com.

\subsection{Inhibition of Pattern Recognition Receptors}

Cystatins may also interfere with the processing of pattern recognition receptors (PRR) [69]. PRR are key elements of the innate immune system. They are mainly expressed on the surface of macrophages, monocytes, dendritic cells, and epithelial cells acting as the first line of defense for parasite detection and capable of recognizing pathogen-associated molecular patterns (PAMPs). PRR include the toll-like receptors (TLRs), cytosolic NOD-like receptors, and the RNA-sensing retinoic acid-inducible gene (RIG)-like helicases [69]. Recognition of PAMPs by PRR leads to the activation of signaling cascades, such as the activation of the NF- $\mathrm{KB}$-dependent pathway along and the interferon regulatory factor pathway, further driving the release of proinflammatory cytokines [70]. By interfering with PRR processing, cystatins might hinder the activation of APC for PAMPs [69].

\subsection{Modulation of Cytokines and Nitric Oxide}

IL-10, an anti-inflammatory cytokine is responsible for optimally modulating Th1 immune responses, APCs, and T cells [71]. IL-10 limits the immunogenic response of APC by terminating excessive T-cell responses, inducing regulatory $\mathrm{T}$ cells, and reducing the production of proinflammatory cytokines [72]. IL-10 mediates its effects on APC through the Janus kinase 1 (JAK1)/Tyrosine kinase 2 (Tyk2)/Signal transducer and activator of transcription 3 (STAT3) pathway [73,74]. Binding of IL-10 to IL-10 receptor $\alpha($ IL-10R $\alpha)$ phosphorylates and activates STAT3 and STAT5 and allows its translocation to the nucleus, which then selectively modulates transcription of anti-inflammatory and inflammatory mediators [75,76]. The parasites may induce immunoregulatory effects by modulating IL-10 milieu in the host [77]. Parasite cystatins are shown to induce IL-10 secretion from macrophages and DC $[59,61,78,79]$. B. malayi cystatin has been shown to induce IL-10 in human monocytes and macrophages via the p38 dependent pathway in monocytes and also the ERK-dependent pathway in macrophages [80]. A. viteae cystatin also mediates IL-10 production in murine macrophages via the tyrosine kinase pathway and is dependent on the activation of mitogen-activated protein kinases (MAPK) [78,81]. The activation of MAPK ERK (extracellular-signal-regulated kinase) and p38 to induce IL-10 production has been negatively regulated by dual specific phosphatases (DUSP) [82]. Both the in-silico approach and in vivo studies showed that $A$. viteae cystatin induces the expression 
of DUSP1 and DUSP2 [81]. A. viteae cystatin also induced phospho-ERK regulated phosphorylation of STAT3 [81]. Similar effects were observed by tick cystatin on bone marrow-derived dendritic cells (BMDC) with effects on p38, ERK (MAPK), and STAT expression strengthening the evidence that cystatins can modulate APC by activating multiple pathways, as shown in Figure 3 [83].

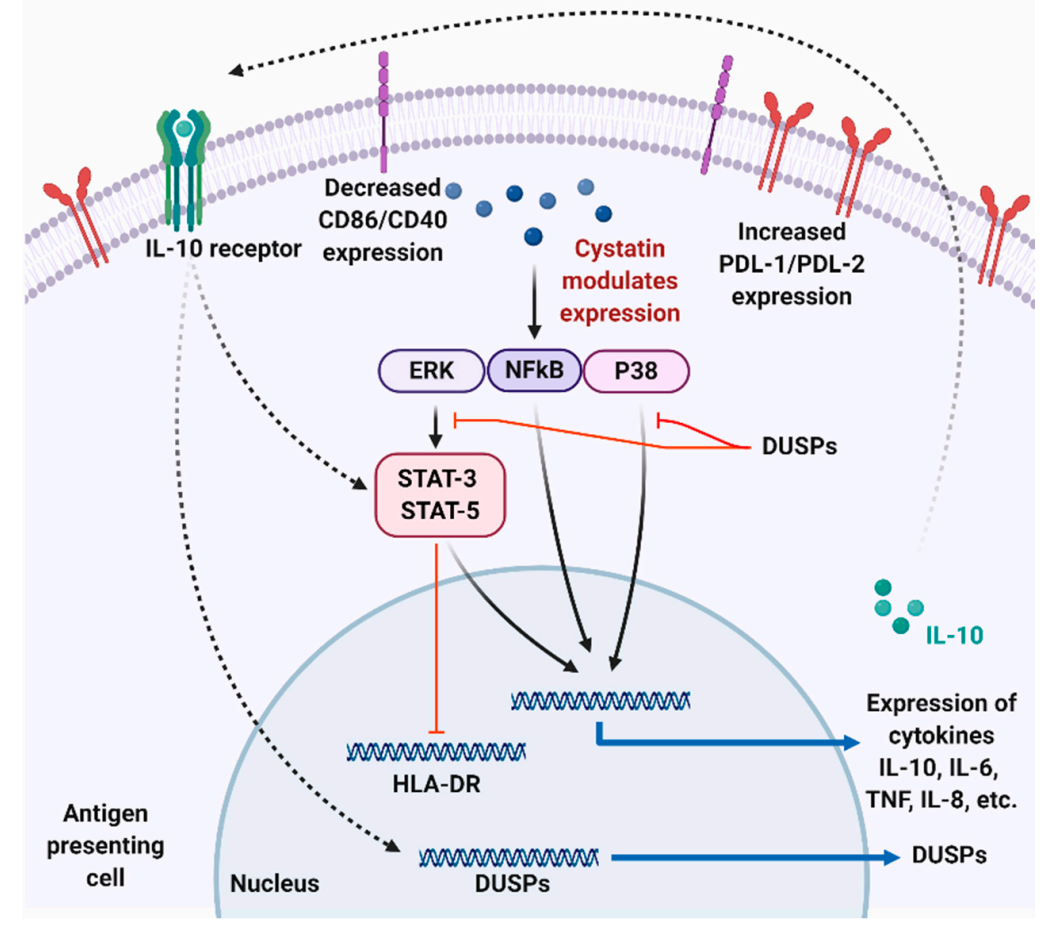

Figure 3. Possible mechanism of parasite cystatin mediated modulation in antigen-presenting cells. Cystatins modulate the ERK, NFkB, and P38 pathways leading to an increased expression of IL-10 and IL- 8 and low expression of TNF- $\alpha$ and IL- 6 cytokines. Secreted IL-10 can then bind to IL-10R on APC, subsequently leading to the expression of dual specific phosphatases (DUSPs) that can negatively modulate NFkB and P38 pathways. Parasite cystatins also reduce the appearance of human leukocyte antigen-DR isotype (HLA-DR), CD86, CD40, and increase expression of PDL-1 and PDL-2 in APC, which can reduce $\mathrm{T}$ cell activation and proliferation. Figure created using Biorender.com.

Like IL-10, NO is another physiologic key molecule modulated by some parasite cystatins. $\mathrm{NO}$ is released by activated macrophages to inhibit parasitic invasion and induce host-protective immune responses, a common phenomenon against infections [59]. However, studies have also shown T-cell suppression by NO in parasitic infections [84-86]. This suggests a dual role played by NO in immune modulation. Cystatins from B. malayi, O. volvulus, A. viteae, and Angiostrongylus cantonensis are shown to induce NO secretion from IFN- $\gamma$ primed macrophages, a response partly dependent on TNF- $\alpha$ and IL-10 $[59,87]$. The mechanism of this NO release is shown to be different from that induced by LPS in murine APC, suggesting that parasite cystatins possibly manipulate APC through a different receptor-mediated pathway. However, recombinant cystatin from Litomosoides sigmodontis and S. japonicum appears to reduce NO secretion from murine peritoneal macrophages $[79,88]$. This effect is different from those observed by others [59,87]. This might be due to the fact that parasite cystatins also trigger IL-10 secretion, and the timing of IL-10 expression has an ambiguous effect on NO secretion. Thus, determining the effect of parasite cystatins on NO release is complicated and can be influenced by the exposure of parasite cystatins to immune cells. This means that parasite cystatins do not induce the NO synthesis pathway, rather they seem to modulate NO production. This provides parasites an extraordinary ability to exert selective phenotypes of macrophages (M1, M2, or alternatively activated macrophages), downregulate macrophage inflammatory responses, 
and inhibit T-cell proliferation $[89,90]$. Our studies have also shown that the B. malayi cystatin could induce alternative activation of murine peritoneal macrophages with decreased NO and increased arginase activity [91]. However, the exact mechanism through which cystatins modulate these responses needs further investigation.

\subsection{Suppression of T-Cell Proliferation}

Filarial cystatins also showed suppression of T-cell proliferation [92]. Acanthocheilonema viteae cystatin can inhibit murine T cell proliferation in vitro [78]. O. volvulus CPI-2 reduces polyclonal and antigen-specific T cell proliferation [61,92]. L. sigmodontis cystatin reduced antigen-specific splenocyte responses in mice [88]. These T-cell suppressive effects of cystatins were associated with IL-10 and NO secretion from macrophages and immune cells [92].

\section{Therapeutic Potential of Parasite Cystatins}

Experimental studies in animal models for CIADs have provided valuable information on the beneficial effects of parasite cystatins (summarized in Table 1). Although these animal models do not exactly reflect the pathology in human disease conditions, the outcomes can be used as a guideline for developing cystatin as biotherapeutics.

Table 1. Summary of animal experiments evaluating the therapeutic effects of parasite cystatins in immune-mediated disorders.

\begin{tabular}{|c|c|c|c|c|}
\hline $\begin{array}{c}\text { Cystatin Derived } \\
\text { from Helminth } \\
\text { Parasite }\end{array}$ & $\begin{array}{l}\text { Experimental } \\
\text { Inflammatory } \\
\text { Condition }\end{array}$ & Outcome of the Study & Mechanism of Action & Reference \\
\hline \multirow{4}{*}{$\begin{array}{c}\text { Acanthocheilonema } \\
\text { viteae }\end{array}$} & $\begin{array}{l}\text { OVA-induced } \\
\text { airway } \\
\text { inflammation } \\
\text { DSS-induced } \\
\text { colitis }\end{array}$ & $\begin{array}{l}\text { Suppressed OVA-induced allergic } \\
\text { airway hyperreactivity } \\
\text { Reduced eosinophil infiltration in } \\
\text { lungs } \\
\text { Reduced levels of the } \\
\text { OVA-specific and total IgE levels } \\
\text { Suppression of DSS-induced } \\
\text { colitis }\end{array}$ & $\begin{array}{l}\text { Macrophage mediated and } \\
\text { IL-10 dependent inhibition } \\
\text { of the disease conditions } \\
\text { Down-regulation of the } \\
\text { Th2-mediated } \\
\text { hyperresponsiveness } \\
\text { Restricted role of Tregs }\end{array}$ & [93] \\
\hline & $\begin{array}{l}\text { Pollen sensitized } \\
\text { allergy }\end{array}$ & $\begin{array}{l}\text { Suppression of allergen-specific } \\
\text { airway inflammation } \\
\text { Reduced eosinophil infiltration, } \\
\text { allergen-specific IgE and IL-5 and } \\
\text { IL-13 cytokine levels in } \\
\text { bronchoalveolar lavage }\end{array}$ & $\begin{array}{l}\text { Increased IL-10 levels from } \\
\text { splenocytes } \\
\text { Shift of immune response } \\
\text { towards Th1 }\end{array}$ & [94] \\
\hline & $\begin{array}{l}\text { DSS-induced } \\
\text { colitis }\end{array}$ & $\begin{array}{l}\text { Utilized genetically modified } \\
\text { probiotic bacterium Escherichia coli } \\
\text { Nissle } 1917 \text { to secrete AvCys in the } \\
\text { gut } \\
\text { Decreased intestinal inflammation } \\
\text { in mice and pigs }\end{array}$ & $\begin{array}{l}\text { Increased Foxp3+ Tregs in } \\
\text { treated mice } \\
\text { Reduced levels of IL- } 6 \text { and } \\
\text { IL-17A, decreased } \\
\text { macrophage inflammatory } \\
\text { protein- } 1 \alpha / \beta \text { and monocyte } \\
\text { chemoattractant protein }-1 / 3 \\
\text { in colon of mice }\end{array}$ & [95] \\
\hline & $\begin{array}{l}\text { OVA-induced } \\
\text { airway } \\
\text { inflammation } \\
\text { DSS-induced } \\
\text { colitis }\end{array}$ & $\begin{array}{l}\text { Adoptive transfer of Mregs } \\
\text { suppressed the OVA-induced } \\
\text { airway inflammation and acute } \\
\text { intestinal inflammation } \\
\text { Suppressed allergen-specific IgE } \\
\text { levels } \\
\text { Reduced influx of eosinophils into } \\
\text { the airways } \\
\text { Reduced mucous production in } \\
\text { bronchioles and lower airway cell } \\
\text { infiltration } \\
\text { Suppressed clinical and } \\
\text { pathological parameters of colitis }\end{array}$ & $\begin{array}{l}\text { Mregs are involved in the } \\
\text { immunosuppressive activity } \\
\text { of cystatin } \\
\text { Cystatin induces conversion } \\
\text { of classical macrophages } \\
\text { towards a suppressive } \\
\text { M2a/M2b hybrid phenotype } \\
\text { Marked reduction in the Th2 } \\
\text { cytokines along with an } \\
\text { associated increase in the } \\
\text { IL-10 levels }\end{array}$ & {$[96]$} \\
\hline
\end{tabular}


Table 1. Cont.

\begin{tabular}{|c|c|c|c|c|}
\hline $\begin{array}{l}\text { Cystatin Derived } \\
\text { from Helminth } \\
\text { Parasite }\end{array}$ & $\begin{array}{l}\text { Experimental } \\
\text { Inflammatory } \\
\text { Condition }\end{array}$ & Outcome of the Study & Mechanism of Action & Reference \\
\hline \multirow{3}{*}{ Brugia malayi } & $\begin{array}{l}\text { DSS-induced } \\
\text { colitis }\end{array}$ & $\begin{array}{l}\text { Reduced severity of the clinical } \\
\text { disease condition } \\
\text { Reduced damage to colon along } \\
\text { with the restricted cellular } \\
\text { infiltration }\end{array}$ & $\begin{array}{l}\text { Reduced expression of Th1 } \\
\text { and Th17 cytokines } \\
\text { Possible role of Tregs and } \\
\text { peritoneal macrophages } \\
\text { Increased IL- } 10^{+} \text {peritoneal } \\
\text { B1 cells }\end{array}$ & {$[3,91]$} \\
\hline & $\begin{array}{l}\text { mBSA-induced } \\
\text { rheumatoid } \\
\text { arthritis }\end{array}$ & $\begin{array}{l}\text { Both preventive and therapeutic } \\
\text { suppressive effect on the RA } \\
\text { Reduced paw swelling and } \\
\text { cartilage destruction }\end{array}$ & $\begin{array}{l}\text { Dominant Th2 immune } \\
\text { responses with up-regulated } \\
\text { IL-10 cytokine levels }\end{array}$ & {$[97,98]$} \\
\hline & $\begin{array}{l}\text { DSS-induced } \\
\text { chronic colitis }\end{array}$ & $\begin{array}{l}\text { Improved clinicopathologic } \\
\text { condition of chronic colitis }\end{array}$ & $\begin{array}{l}\text { Upregulated mRNA } \\
\text { expression of IL-10 and } \\
\text { TGF- } \beta \\
\text { Reduced NF- } \kappa B \text { levels in } \\
\text { colon }\end{array}$ & {$[99,100]$} \\
\hline \multirow{4}{*}{$\begin{array}{l}\text { Schistosoma } \\
\text { japonicum }\end{array}$} & $\begin{array}{l}\text { CIA-induced } \\
\text { arthritis }\end{array}$ & Prevented cartilage destruction & $\begin{array}{l}\text { Inhibitory modulation of } \\
\text { Th1 and Th17 } \\
\text { Upregulation of Tregs and } \\
\text { Th2 shift of immune system }\end{array}$ & [101] \\
\hline & $\begin{array}{l}\text { TNBS-induced } \\
\text { colitis }\end{array}$ & $\begin{array}{l}\text { Reduced clinical disease } \\
\text { parameters and ameliorated the } \\
\text { severity of the disease condition }\end{array}$ & $\begin{array}{l}\text { Decreased CD } 4+\mathrm{IFN} \gamma+ \\
\text { expressing Th cell subsets in } \\
\text { spleen, MLN and LPMC } \\
\text { Upregulated expression of } \\
\text { Th2 and regulatory } \\
\text { cytokines (IL-4, IL-13, IL-10, } \\
\text { and TGF- } \beta \text { ) in the colon } \\
\text { tissues } \\
\text { Up-trending Tregs in the } \\
\text { MLN and LPMC }\end{array}$ & [102] \\
\hline & Sepsis & $\begin{array}{l}\text { About } 60-80 \% \text { survival rate after } \\
\text { rSj-Cys treatment } \\
\text { Reduced disease pathology }\end{array}$ & $\begin{array}{l}\text { Reduced serum levels of } \\
\text { TNF- } \alpha, \text { IL- } 6 \text {, and IL- } 1 \beta \\
\text { cytokines }\end{array}$ & [103] \\
\hline & $\begin{array}{l}\text { Type-1 diabetes; } \\
\text { NOD mice }\end{array}$ & $\begin{array}{l}60 \% \text { reduction in diabetes } \\
\text { incidence } \\
\text { Preserved islet cells pathology in } \\
\text { treated animals }\end{array}$ & $\begin{array}{l}\text { Increased Treg cells } \\
\text { Reduced IFN- } \gamma \text { and } \\
\text { increased IL-4, IL-10, and } \\
\text { TGF- } \beta \text { levels in spleens and } \\
\text { PLN }\end{array}$ & [104] \\
\hline \multirow[b]{2}{*}{ Ascaris lumbricoides } & $\begin{array}{l}\text { DSS-induced } \\
\text { colitis }\end{array}$ & $\begin{array}{l}\text { Inhibition of the disease condition } \\
\text { Significant reduction in disease } \\
\text { activity score, myeloperoxidase } \\
\text { activity and histopathological } \\
\text { damage of colon }\end{array}$ & $\begin{array}{l}\text { IL-10 and TGF-B gene } \\
\text { overexpression in rAl-CPI } \\
\text { treated colitis mice }\end{array}$ & [105] \\
\hline & $\begin{array}{l}\text { HDM-induced } \\
\text { allergic airway } \\
\text { inflammation }\end{array}$ & $\begin{array}{l}\text { Significantly reduced allergy } \\
\text { symptoms in treated mice } \\
\text { Reduced cellular infiltration in } \\
\text { BAL }\end{array}$ & $\begin{array}{l}\text { Decreased allergy specific } \\
\text { Th2 immune response } \\
\text { Decreased total and IgE } \\
\text { specific antibodies } \\
\text { Increased Tregs in spleen } \\
\text { and IL-10 in BAL and spleen } \\
\text { HmoDCs with lowered } \\
\text { expression of HLA-DR, } \\
\text { CD83, and CD86 }\end{array}$ & {$[62]$} \\
\hline Clonorchis sinensis & $\begin{array}{l}\text { DSS-induced } \\
\text { colitis }\end{array}$ & $\begin{array}{l}\text { Curative treatment lead to the } \\
\text { amelioration of the disease } \\
\text { condition }\end{array}$ & & [106] \\
\hline
\end{tabular}

OVA: ovalbumin; DSS: dextan sulfate sodium; RA: rheumatoid arthritis; mBSA: methylated bovine serum albumin; TNBS: tri-nitrobenzene sulfonic acid; CIA: collagen-induced arthritis; MLN: mysenteric lymph nodes; LPMC: lamina propria mononuclear cells; NOD: non-obese diabetic; PLN: peripheral lymph nodes; HDM: house dust mite; BAL: bronchoalveolar lavage; HmoDCs: human monocyte-derived dendritic cells; HLA-DR: human leukocyte antigen-DR isotype. 


\subsection{Inflammatory Bowel Disease}

Inflammatory bowel disease (IBD) is a chronic and relapsing inflammatory condition of the gastrointestinal tract. According to the Centers for disease control and prevention (CDC), about $1.3 \%$ of United States' adults have been diagnosed with IBD. Therapeutic effects of cystatins are widely tested in various chemically induced and knockout animal models for IBD. Schnoeller et al. [93] were the first to demonstrate the therapeutic potential of a recombinant cystatin from A. viteae (Av17) in murine models of dextran sodium sulfate (DSS)-induced colitis. Av17-treated colitis animals showed a significant reduction in the colitis inflammatory index and also improved pathology of the colon with less inflammatory cell infiltrations. Another study using AvCystatin, highlighted the role of IL-10 from regulatory macrophages (Mregs) in the suppression of the colitis conditions [96]. Transfer of AvCystatin-Mregs to DSS-colitis mice protected animals from developing clinical signs of colitis. AvCystatin-Mregs isolated from the peritoneum of treated mice showed increased expression of $M 2 b$ markers and arginase-1. This study also showed a transient expression of IL-10 in macrophages by AvCystatin uses MAPK signaling pathways. A synergistic effect of genetically modified a probiotic bacterium E. coli Nissle 1917 to secrete A. viteae cystatin has shown extraordinary effects in reducing intestinal inflammation in both mice and pigs [95].

Our group has shown the therapeutic capabilities of cystatin from filarial a parasite B. malayi ( $\mathrm{rBmaCys)}$ in both acute and chronic colitis. $\mathrm{rBmaCys-treatment} \mathrm{given} \mathrm{to} \mathrm{DSS-induced} \mathrm{colitis} \mathrm{mice}$ reduced the clinical and pathological severity of disease conditions in mice $[3,99,100]$. The effect was associated with an upregulated expression of IL-10 and decreased expression of IFN- $\gamma$, TNF- $\alpha$, IL-5, IL-6, and IL-17 in the treated mice. Recently, we could show that IL-10 producing B1 cells in the peritoneal cavity of mice may have a possible role in promoting the immunosuppressive effects of $\mathrm{rBmaCys} \mathrm{[91].} \mathrm{Further} \mathrm{studies} \mathrm{are} \mathrm{required} \mathrm{to} \mathrm{confirm} \mathrm{this} \mathrm{observed} \mathrm{therapeutic} \mathrm{role} \mathrm{of} \mathrm{B1} \mathrm{cells.}$

Cystatin from S. japonicum has also been widely tested against experimental colitis. rSjcystatin administration significantly ameliorated the tri-nitrobenzene sulfonic acid (TNBS)-induced colitis with increased Tregs in mesenteric lymph nodes (MLN) and lamina propria mononuclear cells (LPMC) of the treated mice [102]. The observed therapeutic effect of cystatin is believed to be through the modulation and suppression of local inflammatory responses, downregulation of Th1 immune responses, elevation of CD4+ CD25+ Foxp3+ Treg cells in the MLN, and upregulated expression of Th2 and regulatory markers IL-10, TGF- $\beta$, and Foxp3 in treated mice. There was an increase in the alternatively activated intestinal macrophages (M2-like cells) in the rSjCystatin-treated mice. A similar observation was reported by several other research groups as well $[93,103,106]$. Taken together, these findings suggest a more prominent role for cystatin-activated peritoneal macrophages in the disease attenuation.

Cystatins from other parasites, such as Ascaris lumbricoides and Clonorchis sinensis, have also shown potential ameliorative effects on DSS-induced colitis in experimental animals [105,106]. In mice with induced colitis, when treated with C. sinensis Stefin-1, the IL-10 levels were significantly increased in the spleen and MLN along with an increase in IL-10+ F4/80+ macrophages. These studies demonstrate the potential of parasite cystatin as a biotherapeutic for colitis.

\subsection{Allergies}

About $10-30 \%$ of the world's population is affected by allergies [107]. Allergies are the most common and prominent inflammatory disorders. Surprisingly, parasite cystatins have been shown to suppress induced allergic conditions in experimental animals [18]. Treatment with A. viteae cystatin (Av17) in a murine model of OVA-induced allergic airway responsiveness significantly inhibited the eosinophil recruitment into the lungs of treated mice, lowered the levels of antigen-specific and total IgE, thereby reducing sensitization to mast cells and basophils [93]. A predominant role for Av17 activated macrophages in the suppression of allergic conditions and a role for $\mathrm{T}$ regulatory cells in the cystatin-induced suppression of inflammation and alleviation of symptoms was observed [93]. Subsequently, a single adoptive transfer of Mreg cells from A. viteae cystatin treated mice followed by the induction of the allergen challenge resulted in the suppression of allergen-specific IgE and 
reduced the infiltration of eosinophils into the lungs of mice with suppression of generalized Th2 immune responses in the lungs [96]. A. viteae cystatin treatment also alleviated the timothy grass pollen-induced allergic responses in a mouse model [94]. Surprisingly, increased secretion of IFN- $\gamma$ was observed from CD4+ T cells in A. viteae cystatin treated mice. This increased IFN- $\gamma$ seems to have beneficial effects in suppressing allergen-specific Th2 immune cells, a response observed in atopic patients after immunotherapy [108]. However, how A. viteae cystatin induces both IL-10 and IFN- $\gamma$ to reduce allergic condition is not clear yet and needs further investigation. A recent study showed A. lumbricoides cystatin (rAl-CPI) treatment significantly reduced house dust mite-induced allergic airway inflammation [62]. After exposing human monocyte-derived DCs (HmoDCs) to rAl-CPI, the expression of HLA-DR, CD83, and CD86 was lowered with a concomitant increase in the expression of IL-10 and a decrease in the expression of IL-6 [62]. These findings demonstrate that the parasite cystatin has ameliorative effects on allergic conditions.

\subsection{Rheumatoid Arthritis}

Rheumatoid arthritis is a chronic inflammatory condition of joints. This disease affects approximately 54.4 million (25\%) people in the United States and is estimated to affect over 78 million by 2040 [109]. Several studies show that both preventive and therapeutic administration of B. malayi cystatin could suppress the severity of mBSA-induced arthritis $[97,98]$. Treated animals showed a reduction in paw swelling and a reduction in clinical disease parameters accompanied by a Th2 dominant immune response $[97,98]$. Collagen-induced arthritis in DBA/1 mice was significantly attenuated following rSjCystatin treatment. These treated mice had upregulation of Treg cells and a skewed Th2 dominant immune response in the periphery with inhibition of Th1 and Th17 immune responses [101]. The mechanism of cystatin-induced suppression of arthritis appears to be a general suppression of RANKL (receptor activator of nuclear factor kappa-B ligand) expression in osteoclasts [97]. RANKL is essential for differentiation and activation of osteoclasts and synoviocytes [110]. Additional studies are required to establish the mechanisms by which cystatin induces its therapeutic effects in rheumatoid arthritis.

In addition to these three diseases (IBD, allergy, and rheumatoid arthritis), cystatin treatment has been found to be highly effective in other immune-mediated disorders, such as sepsis and type-1 diabetes $[103,104]$. SjCystatin treatment for sepsis was associated with a reduced expression of MyD88, a canonical adaptor molecule for inflammatory TLR signaling pathways in the liver, kidney, and lung tissues of the treated mice [103]. In addition, there were elevated levels of IL-10 and TGF- $\beta 1$ in the sera of treated mice. This study suggests that SjCystatin could stimulate increased secretion of inhibitory cytokines from Tregs and other immune cells, which in turn can change the proinflammatory cell phenotypes. This activity of SjCystatin can be through modulation of TLR-MyD88 activation pathway in immune cells. rSjCystatin treatment also reduced the development of type-1 diabetes (up to 60\%) in non-obese diabetic mice [104]. The islet cells' pathology was conserved in treated mice with increased Tregs in spleens and PLN. Collectively, these experimental studies indicate that parasite cystatin has tremendous potential as a biotherapeutic molecule for CIADs.

\section{Conclusions}

Immune-mediated conditions are complex, and the incidence of these disorders is overwhelmingly increasing. Better therapies and cure are urgently needed. Epidemiological and experimental evidences support the principle of helminth therapy (HT). Given the limitations of the use of HT, much attention has been recently focused on identifying specific immunomodulatory molecules of the parasites and evaluating their biotherapeutic potential in various CIADs. Among the various molecules identified, cystatins of helminth parasites are the most extensively studied immunomodulatory molecules with demonstrated activity as a biotherapeutic molecule for CIADs. Studies in various experimental animal models confirm the therapeutic potential of this molecule. Several studies attempted to identify the mechanism by which cystatin induces its immunomodulatory activity. These studies identified a role 
for macrophages, IL-10, regulatory cells, and several receptors and signaling molecules. Nevertheless, there is a need to identify the comprehensive mechanism by which parasite cystatin induces the generalized immunosuppression, which can be harnessed to develop this molecule further as a therapeutic molecule for treating autoimmune conditions including CIADs.

Author Contributions: All authors wrote the manuscript. All authors have read and agreed to the published version of the manuscript.

Funding: The financial support by National Institutes of Health (NIH), USA grant RO1AI116441 (RK), and the Blazer Foundation of Rockford, USA grant \# 344524, is gratefully acknowledged.

Conflicts of Interest: The authors report no conflict of interest.

\section{References}

1. Lerner, A.; Jeremias, P.; Matthias, T. The world incidence and prevalence of autoimmune diseases is increasing. Int. J. Celiac Dis. 2015, 3, 5. [CrossRef]

2. Taghipour, N.; Aghdaei, H.A.; Haghighi, A.; Mossafa, N.; Tabaei, S.J.; Rostami-Nejad, M. Potential treatment of inflammatory bowel disease: A review of helminths therapy. Gastroenterol. Hepatol. Bed Bench 2014, 7, 9-16. [PubMed]

3. Khatri, V.; Amdare, N.; Yadav, R.S.; Tarnekar, A.; Goswami, K.; Reddy, M.V. Brugia malayi abundant larval transcript 2 protein treatment attenuates experimentally-induced colitis in mice. Indian J. Exp. Biol. 2015, 53, 732-739.

4. Lopes, F.; Matisz, C.; Reyes, J.L.; Ijon, H.; Al-Darmaki, A.; Kaplan, G.G.; McKay, D.M. Helminth Regulation of Immunity: A Three-pronged Approach to Treat Colitis. Inflamm. Bowel Dis. 2016, 22, 2499-2512. [CrossRef] [PubMed]

5. Caraballo, L. The tropics, helminth infections and hygiene hypotheses. Expert Rev. Clin. Immunol. 2018, 14, 99-102. [CrossRef] [PubMed]

6. Hedley, L.; Wani, R.L. Helminth infections: Diagnosis and treatment. Pharm. J. 2015, 295. [CrossRef]

7. World Health Organization. Soil-Transmitted Helminth Infections. Available online: http://www.who.int/ mediacentre/factsheets/fs366/en/ (accessed on 19 February 2020).

8. Maizels, R.M.; Smits, H.H.; McSorley, H.J. Modulation of Host Immunity by Helminths: The Expanding Repertoire of Parasite Effector Molecules. Immunity 2018, 49, 801-818. [CrossRef]

9. Kaplan, G.G. IBD: Global variations in environmental risk factors for IBD. Nat. Rev. Gastroenterol. Hepatol. 2014, 11, 708-709. [CrossRef]

10. Bach, J.F. The hygiene hypothesis in autoimmunity: The role of pathogens and commensals. Nat. Rev. Immunol. 2018, 18, 105-120. [CrossRef]

11. Greenwood, B.M. Autoimmune disease and parasitic infections in Nigerians. Lancet 1968, 2, 380-382. [CrossRef]

12. Strachan, D.P. Hay fever, hygiene, and household size. BMJ 1989, 299, 1259-1260. [CrossRef] [PubMed]

13. Rook, G.A.; Martinelli, R.; Brunet, L.R. Innate immune responses to mycobacteria and the downregulation of atopic responses. Curr. Opin. Allergy Clin. Immunol. 2003, 3, 337-342. [CrossRef] [PubMed]

14. Aravindhan, V.; Mohan, V.; Surendar, J.; Muralidhara Rao, M.; Pavankumar, N.; Deepa, M.; Rajagopalan, R.; Kumaraswami, V.; Nutman, T.B.; Babu, S. Decreased prevalence of lymphatic filariasis among diabetic subjects associated with a diminished pro-inflammatory cytokine response (CURES 83). PLoS Negl. Trop. Dis. 2010, 4, e707. [CrossRef] [PubMed]

15. Aoyama, H.; Hirata, T.; Sakugawa, H.; Watanabe, T.; Miyagi, S.; Maeshiro, T.; Chinen, T.; Kawane, M.; Zaha, O.; Nakayoshi, T.; et al. An inverse relationship between autoimmune liver diseases and Strongyloides stercoralis infection. Am. J. Trop. Med. Hyg. 2007, 76, 972-976. [CrossRef]

16. Gazzinelli-Guimaraes, P.H.; Nutman, T.B. Helminth parasites and immune regulation. F1000Research 2018, 7. [CrossRef]

17. Smallwood, T.B.; Giacomin, P.R.; Loukas, A.; Mulvenna, J.P.; Clark, R.J.; Miles, J.J. Helminth Immunomodulation in Autoimmune Disease. Front. Immunol. 2017, 8, 453. [CrossRef]

18. Sobotkova, K.; Parker, W.; Leva, J.; Ruzkova, J.; Lukes, J.; Jirku Pomajbikova, K. Helminth Therapy-From the Parasite Perspective. Trends Parasitol. 2019, 35, 501-515. [CrossRef] 
19. Maruszewska-Cheruiyot, M.; Donskow-Lysoniewska, K.; Doligalska, M. Helminth Therapy: Advances in the use of Parasitic Worms against Inflammatory Bowel Diseases and its Challenges. Helminthologia 2018, 55, 1-11. [CrossRef]

20. Ruyssers, N.E.; De Winter, B.Y.; De Man, J.G.; Loukas, A.; Pearson, M.S.; Weinstock, J.V.; Van den Bossche, R.M.; Martinet, W.; Pelckmans, P.A.; Moreels, T.G. Therapeutic potential of helminth soluble proteins in TNBS-induced colitis in mice. Inflamm. Bowel Dis. 2009, 15, 491-500. [CrossRef]

21. Heylen, M.; Ruyssers, N.E.; De Man, J.G.; Timmermans, J.P.; Pelckmans, P.A.; Moreels, T.G.; De Winter, B.Y. Worm proteins of Schistosoma mansoni reduce the severity of experimental chronic colitis in mice by suppressing colonic proinflammatory immune responses. PLoS ONE 2014, 9, e110002. [CrossRef]

22. Hasby, E.A.; Hasby Saad, M.A.; Shohieb, Z.; El Noby, K. FoxP3+ T regulatory cells and immunomodulation after Schistosoma mansoni egg antigen immunization in experimental model of inflammatory bowel disease. Cell. Immunol. 2015, 295, 67-76. [CrossRef] [PubMed]

23. Xia, C.M.; Zhao, Y.; Jiang, L.; Jiang, J.; Zhang, S.C. Schistosoma japonicum ova maintains epithelial barrier function during experimental colitis. World J. Gastroenterol. 2011, 17, 4810-4816. [CrossRef] [PubMed]

24. Haarder, S.; Kania, P.W.; Holm, T.L.; von Gersdorff Jorgensen, L.; Buchmann, K. Effect of ES products from Anisakis (Nematoda: Anisakidae) on experimentally induced colitis in adult zebrafish. Parasite Immunol. 2017, 39. [CrossRef] [PubMed]

25. Eissa, M.M.; Mostafa, D.K.; Ghazy, A.A.; El Azzouni, M.Z.; Boulos, L.M.; Younis, L.K. Anti-Arthritic Activity of Schistosoma mansoni and Trichinella spiralis Derived-Antigens in Adjuvant Arthritis in Rats: Role of FOXP3+ Treg Cells. PLoS ONE 2016, 11, e0165916. [CrossRef]

26. Sewell, D.; Qing, Z.; Reinke, E.; Elliot, D.; Weinstock, J.; Sandor, M.; Fabry, Z. Immunomodulation of experimental autoimmune encephalomyelitis by helminth ova immunization. Int. Immunol. 2003, 15, 59-69. [CrossRef]

27. Hansen, C.S.; Hasseldam, H.; Bacher, I.H.; Thamsborg, S.M.; Johansen, F.F.; Kringel, H. Trichuris suis secrete products that reduce disease severity in a multiple sclerosis model. Acta Parasitol. 2017, 62, 22-28. [CrossRef]

28. Amdare, N.; Khatri, V.; Yadav, R.S.; Tarnekar, A.; Goswami, K.; Reddy, M.V. Brugia malayi soluble and excretory-secretory proteins attenuate development of streptozotocin-induced type 1 diabetes in mice. Parasite Immunol. 2015, 37, 624-634. [CrossRef]

29. Wu, Z.; Wang, L.; Tang, Y.; Sun, X. Parasite-Derived Proteins for the Treatment of Allergies and Autoimmune Diseases. Front. Microbiol. 2017, 8, 2164. [CrossRef]

30. Heylen, M.; Ruyssers, N.E.; Gielis, E.M.; Vanhomwegen, E.; Pelckmans, P.A.; Moreels, T.G.; De Man, J.G.; De Winter, B.Y. Of worms, mice and man: An overview of experimental and clinical helminth-based therapy for inflammatory bowel disease. Pharmacol. Ther. 2014, 143, 153-167. [CrossRef]

31. Klotz, C.; Ziegler, T.; Daniłowicz-Luebert, E.; Hartmann, S. Cystatins of Parasitic Organisms. In Cysteine Proteases of Pathogenic Organisms. Advances in Experimental Medicine and Biology; Robinson, M.W., Dalton, J.P., Eds.; Springer: Boston, MA, USA, 2011; Volume 712.

32. Bird, P.I.; Trapani, J.A.; Villadangos, J.A. Endolysosomal proteases and their inhibitors in immunity. Nat. Rev. Immunol. 2009, 9, 871-882. [CrossRef]

33. Prunk, M.; Perišić Nanut, M.; Sabotič, J.; Kos, J. Cystatins, cysteine peptidase inhibitors, as regulators of immune cell cytotoxicity. Period. Biol. 2016, 118, 9. [CrossRef]

34. Gabrijelcic, D.; Annan-Prah, A.; Rodic, B.; Rozman, B.; Cotic, V.; Turk, V. Determination of cathepsins B and $\mathrm{H}$ in sera and synovial fluids of patients with different joint diseases. J. Clin. Chem. Clin. Biochem. 1990, 28, 149-153. [CrossRef] [PubMed]

35. Lenarcic, B.; Gabrijelcic, D.; Rozman, B.; Drobnic-Kosorok, M.; Turk, V. Human cathepsin B and cysteine proteinase inhibitors (CPIs) in inflammatory and metabolic joint diseases. Biol. Chem. Hoppe Seyler 1988, 369, 257-261. [PubMed]

36. Trabandt, A.; Aicher, W.K.; Gay, R.E.; Sukhatme, V.P.; Nilson-Hamilton, M.; Hamilton, R.T.; McGhee, J.R.; Fassbender, H.G.; Gay, S. Expression of the collagenolytic and Ras-induced cysteine proteinase cathepsin $\mathrm{L}$ and proliferation-associated oncogenes in synovial cells of MRL/I mice and patients with rheumatoid arthritis. Matrix 1990, 10, 349-361. [CrossRef]

37. Brage, M.; Lie, A.; Ransjo, M.; Kasprzykowski, F.; Kasprzykowska, R.; Abrahamson, M.; Grubb, A.; Lerner, U.H. Osteoclastogenesis is decreased by cysteine proteinase inhibitors. Bone 2004, 34, $412-424$. [CrossRef] 
38. Gregory, W.F.; Maizels, R.M. Cystatins from filarial parasites: Evolution, adaptation and function in the host-parasite relationship. Int. J. Biochem. Cell Biol. 2008, 40, 1389-1398. [CrossRef]

39. Pettersen, E.F.; Goddard, T.D.; Huang, C.C.; Couch, G.S.; Greenblatt, D.M.; Meng, E.C.; Ferrin, T.E. UCSF Chimera-A visualization system for exploratory research and analysis. J. Comput. Chem. 2004, 25, 1605-1612. [CrossRef]

40. Zavasnik-Bergant, T. Cystatin protease inhibitors and immune functions. Front. Biosci. 2008, 13, $4625-4637$. [CrossRef]

41. Rinne, A.; Dorn, A.; Jarvinen, M.; Alavaikko, M.; Jokinen, K.; Hopsu-Havu, V.K. Immunoelectron microscopical location of the acid cysteine proteinase inhibitor in the lymphatic tissue of the tonsils. Acta Histochem. 1986, 79, 137-145. [CrossRef]

42. Turk, V.; Stoka, V.; Vasiljeva, O.; Renko, M.; Sun, T.; Turk, B.; Turk, D. Cysteine cathepsins: From structure, function and regulation to new frontiers. Biochim. Biophys. Acta 2012, 1824, 68-88. [CrossRef]

43. Scott, D.K.; Lord, R.; Muller, H.K.; Malley, R.C.; Woods, G.M. Proteomics identifies enhanced expression of stefin A in neonatal murine skin compared with adults: Functional implications. Br. J. Dermatol. 2007, 156, 1156-1162. [CrossRef] [PubMed]

44. Verdot, L.; Lalmanach, G.; Vercruysse, V.; Hartmann, S.; Lucius, R.; Hoebeke, J.; Gauthier, F.; Vray, B. Cystatins up-regulate nitric oxide release from interferon-gamma-activated mouse peritoneal macrophages. J. Biol. Chem. 1996, 271, 28077-28081. [CrossRef] [PubMed]

45. Joensuu, T.; Kuronen, M.; Alakurtti, K.; Tegelberg, S.; Hakala, P.; Aalto, A.; Huopaniemi, L.; Aula, N.; Michellucci, R.; Eriksson, K.; et al. Cystatin B: Mutation detection, alternative splicing and expression in progressive myclonus epilepsy of Unverricht-Lundborg type (EPM1) patients. Eur. J. Hum. Genet. 2007, 15, 185-193. [CrossRef] [PubMed]

46. Pennacchio, L.A.; Lehesjoki, A.E.; Stone, N.E.; Willour, V.L.; Virtaneva, K.; Miao, J.; D’Amato, E.; Ramirez, L.; Faham, M.; Koskiniemi, M.; et al. Mutations in the gene encoding cystatin B in progressive myoclonus epilepsy (EPM1). Science 1996, 271, 1731-1734. [CrossRef]

47. Korber, I.; Katayama, S.; Einarsdottir, E.; Krjutskov, K.; Hakala, P.; Kere, J.; Lehesjoki, A.E.; Joensuu, T. Gene-Expression Profiling Suggests Impaired Signaling via the Interferon Pathway in $\mathrm{Cstb}^{-/-}$Microglia. PLoS ONE 2016, 11, e0158195. [CrossRef]

48. Kopitar-Jerala, N. The Role of Stefin B in Neuro-inflammation. Front. Cell. Neurosci. 2015, 9, 458. [CrossRef]

49. Perisic Nanut, M.; Sabotic, J.; Jewett, A.; Kos, J. Cysteine cathepsins as regulators of the cytotoxicity of NK and T cells. Front. Immunol. 2014, 5, 616. [CrossRef]

50. Soond, S.M.; Kozhevnikova, M.V.; Townsend, P.A.; Zamyatnin, A.A., Jr. Cysteine Cathepsin Protease Inhibition: An update on its Diagnostic, Prognostic and Therapeutic Potential in Cancer. Pharmaceuticals 2019, 12, 87. [CrossRef]

51. Levey, A.S.; Coresh, J.; Tighiouart, H.; Greene, T.; Inker, L.A. Measured and estimated glomerular filtration rate: Current status and future directions. Nat. Rev. Nephrol. 2020, 16, 51-64. [CrossRef]

52. Teaford, H.R.; Barreto, J.N.; Vollmer, K.J.; Rule, A.D.; Barreto, E.F. Cystatin C: A Primer for Pharmacists. Pharmacy 2020, 8, 35. [CrossRef]

53. Pierre, P.; Mellman, I. Developmental regulation of invariant chain proteolysis controls MHC class II trafficking in mouse dendritic cells. Cell 1998, 93, 1135-1145. [CrossRef]

54. Alvarez-Fernandez, M.; Barrett, A.J.; Gerhartz, B.; Dando, P.M.; Ni, J.; Abrahamson, M. Inhibition of mammalian legumain by some cystatins is due to a novel second reactive site. J. Biol. Chem. 1999, 274, 19195-19203. [CrossRef] [PubMed]

55. Hartmann, S.; Lucius, R. Modulation of host immune responses by nematode cystatins. Int. J. Parasitol. 2003, 33, 1291-1302. [CrossRef]

56. Sadegh-Nasseri, S.; Kim, A. MHC Class II Auto-Antigen Presentation is Unconventional. Front. Immunol. 2015, 6, 372. [CrossRef] [PubMed]

57. Bossowska-Nowicka, M.; Mielcarska, M.B.; Romaniewicz, M.; Kaczmarek, M.M.; Gregorczyk-Zboroch, K.P.; Struzik, J.; Grodzik, M.; Gierynska, M.M.; Toka, F.N.; Szulc-Dabrowska, L. Ectromelia virus suppresses expression of cathepsins and cystatins in conventional dendritic cells to efficiently execute the replication process. BMC Microbiol. 2019, 19, 92. [CrossRef] 
58. Zhao, P.; Zhou, X.M.; Zou, J.; Wang, W.; Wang, L.; Peng, X.B.; Sun, M.X. Comprehensive analysis of cystatin family genes suggests their putative functions in sexual reproduction, embryogenesis, and seed formation. J. Exp. Bot. 2014, 65, 5093-5107. [CrossRef]

59. Hartmann, S.; Schonemeyer, A.; Sonnenburg, B.; Vray, B.; Lucius, R. Cystatins of filarial nematodes up-regulate the nitric oxide production of interferon-gamma-activated murine macrophages. Parasite Immunol. 2002, 24, 253-262. [CrossRef]

60. Hashmi, S.; Zhang, J.; Oksov, Y.; Ji, Q.; Lustigman, S. The Caenorhabditis elegans CPI-2a cystatin-like inhibitor has an essential regulatory role during oogenesis and fertilization. J. Biol. Chem. 2006, 281, 28415-28429. [CrossRef]

61. Schonemeyer, A.; Lucius, R.; Sonnenburg, B.; Brattig, N.; Sabat, R.; Schilling, K.; Bradley, J.; Hartmann, S. Modulation of human $\mathrm{T}$ cell responses and macrophage functions by onchocystatin, a secreted protein of the filarial nematode Onchocerca volvulus. J. Immunol. 2001, 167, 3207-3215. [CrossRef]

62. Coronado, S.; Zakzuk, J.; Regino, R.; Ahumada, V.; Benedetti, I.; Angelina, A.; Palomares, O.; Caraballo, L. Ascaris lumbricoides Cystatin Prevents Development of Allergic Airway Inflammation in a Mouse Model. Front. Immunol. 2019, 10, 2280. [CrossRef]

63. Sun, Y.; Liu, G.; Li, Z.; Chen, Y.; Liu, Y.; Liu, B.; Su, Z. Modulation of dendritic cell function and immune response by cysteine protease inhibitor from murine nematode parasite Heligmosomoides polygyrus. Immunology 2013, 138, 370-381. [CrossRef] [PubMed]

64. Kapsenberg, M.L. Dendritic-cell control of pathogen-driven T-cell polarization. Nat. Rev. Immunol. 2003, 3, 984-993. [CrossRef] [PubMed]

65. Zavasnik-Bergant, T.; Vidmar, R.; Sekirnik, A.; Fonovic, M.; Salat, J.; Grunclova, L.; Kopacek, P.; Turk, B. Salivary Tick Cystatin OmC2 Targets Lysosomal Cathepsins S and C in Human Dendritic Cells. Front. Cell. Infect. Microbiol. 2017, 7, 288. [CrossRef] [PubMed]

66. Sun, T.; Wang, F.; Pan, W.; Wu, Q.; Wang, J.; Dai, J. An Immunosuppressive Tick Salivary Gland Protein DsCystatin Interferes With Toll-Like Receptor Signaling by Downregulating TRAF6. Front. Immunol. 2018, 9 , 1245. [CrossRef]

67. Kobpornchai, P.; Flynn, R.J.; Reamtong, O.; Rittisoonthorn, N.; Kosoltanapiwat, N.; Boonnak, K.; Boonyuen, U.; Ampawong, S.; Jiratanh, M.; Tattiyapong, M.; et al. A novel cystatin derived from Trichinella spiralis suppresses macrophage-mediated inflammatory responses. PLoS Negl. Trop. Dis. 2020, 14, e0008192. [CrossRef]

68. Sepulveda, F.E.; Maschalidi, S.; Colisson, R.; Heslop, L.; Ghirelli, C.; Sakka, E.; Lennon-Dumenil, A.M.; Amigorena, S.; Cabanie, L.; Manoury, B. Critical role for asparagine endopeptidase in endocytic Toll-like receptor signaling in dendritic cells. Immunity 2009, 31, 737-748. [CrossRef]

69. Kopitar-Jerala, N. The role of cysteine proteinases and their inhibitors in the host-pathogen cross talk. Curr. Protein Pept. Sci. 2012, 13, 767-775. [CrossRef]

70. Akira, S.; Takeda, K. Toll-like receptor signalling. Nat. Rev. Immunol. 2004, 4, 499-511. [CrossRef]

71. Couper, K.N.; Blount, D.G.; Riley, E.M. IL-10: The master regulator of immunity to infection. J. Immunol. 2008, 180, 5771-5777. [CrossRef]

72. Schulke, S. Induction of Interleukin-10 Producing Dendritic Cells As a Tool to Suppress Allergen-Specific T Helper 2 Responses. Front. Immunol. 2018, 9, 455. [CrossRef]

73. Antoniv, T.T.; Ivashkiv, L.B. Interleukin-10-induced gene expression and suppressive function are selectively modulated by the PI3K-Akt-GSK3 pathway. Immunology 2011, 132, 567-577. [CrossRef] [PubMed]

74. Crawley, J.B.; Williams, L.M.; Mander, T.; Brennan, F.M.; Foxwell, B.M. Interleukin-10 stimulation of phosphatidylinositol 3-kinase and p70 S6 kinase is required for the proliferative but not the antiinflammatory effects of the cytokine. J. Biol. Chem. 1996, 271, 16357-16362. [CrossRef] [PubMed]

75. Saraiva, M.; Vieira, P.; O'Garra, A. Biology and therapeutic potential of interleukin-10. J. Exp. Med. $2020,217$. [CrossRef] [PubMed]

76. Sarma, U.; Maiti, M.; Bhadange, S.; Nair, A.; Srivastava, A.; Saha, B.; Mukherjee, D. Quantitative modeling of STAT1 and STAT3 dynamics in IFN $\gamma$ and IL-10 pathways uncovered robustness of anti-inflammatory STAT3 signaling. bioRxiv 2019, 425868. [CrossRef]

77. Mills, K.H. Regulatory T cells: Friend or foe in immunity to infection? Nat. Rev. Immunol. 2004, 4, 841-855. [CrossRef] 
78. Hartmann, S.; Kyewski, B.; Sonnenburg, B.; Lucius, R. A filarial cysteine protease inhibitor down-regulates T cell proliferation and enhances interleukin-10 production. Eur. J. Immunol. 1997, 27, 2253-2260. [CrossRef]

79. Yang, X.; Liu, J.; Yue, Y.; Chen, W.; Song, M.; Zhan, X.; Wu, Z. Cloning, expression and characterisation of a type II cystatin from Schistosoma japonicum, which could regulate macrophage activation. Parasitol. Res. 2014, 113, 3985-3992. [CrossRef]

80. Venugopal, G.; Mueller, M.; Hartmann, S.; Steinfelder, S. Differential immunomodulation in human monocytes versus macrophages by filarial cystatin. PLoS ONE 2017, 12, e0188138. [CrossRef]

81. Klotz, C.; Ziegler, T.; Figueiredo, A.S.; Rausch, S.; Hepworth, M.R.; Obsivac, N.; Sers, C.; Lang, R.; Hammerstein, P.; Lucius, R.; et al. A helminth immunomodulator exploits host signaling events to regulate cytokine production in macrophages. PLoS Pathog. 2011, 7, e1001248. [CrossRef]

82. Yoshimura, A.; Naka, T.; Kubo, M. SOCS proteins, cytokine signalling and immune regulation. Nat. Rev. Immunol. 2007, 7, 454-465. [CrossRef]

83. Wei, N.; Lin, Z.; Xu, Z.; Gong, H.; Zhang, H.; Zhou, Y.; Cao, J.; Li, G.; Zhou, J. Immunosuppressive effects of tick protein RHcyst-1 on murine bone marrow-derived dendritic cells. Parasites Vectors 2019, 12, 169. [CrossRef] [PubMed]

84. O'Connor, R.A.; Jenson, J.S.; Devaney, E. NO contributes to proliferative suppression in a murine model of filariasis. Infect. Immun. 2000, 68, 6101-6107. [CrossRef] [PubMed]

85. Villalobo, A. Nitric oxide and cell proliferation. FEBS J. 2006, 273, 2329-2344. [CrossRef] [PubMed]

86. Dasgupta, S.; Mookerjee, A.; Chowdhury, S.K.; Ghose, A.C. Immunosuppression in hamsters with progressive visceral leishmaniasis: An evaluation of the role of nitric oxide toward impairment of the lymphoproliferative response. Parasitol. Res. 1999, 85, 594-596. [CrossRef]

87. Liu, Y.H.; Han, Y.P.; Li, Z.Y.; Wei, J.; He, H.J.; Xu, C.Z.; Zheng, H.Q.; Zhan, X.M.; Wu, Z.D.; Lv, Z.Y. Molecular cloning and characterization of cystatin, a cysteine protease inhibitor, from Angiostrongylus cantonensis. Parasitol. Res. 2010, 107, 915-922. [CrossRef]

88. Pfaff, A.W.; Schulz-Key, H.; Soboslay, P.T.; Taylor, D.W.; MacLennan, K.; Hoffmann, W.H. Litomosoides sigmodontis cystatin acts as an immunomodulator during experimental filariasis. Int. J. Parasitol. 2002, 32, 171-178. [CrossRef]

89. Noel, W.; Raes, G.; Hassanzadeh Ghassabeh, G.; De Baetselier, P.; Beschin, A. Alternatively activated macrophages during parasite infections. Trends Parasitol. 2004, 20, 126-133. [CrossRef]

90. Rolot, M.; Dewals, B.G. Macrophage Activation and Functions during Helminth Infection: Recent Advances from the Laboratory Mouse. J. Immunol. Res. 2018, 2018, 2790627. [CrossRef]

91. Bisht, N.; Khatri, V.; Chauhan, N.; Kalyanasundaram, R. Cystatin from Filarial Parasites Suppress the Clinical Symptoms and Pathology of Experimentally Induced Colitis in Mice by Inducing T-Regulatory Cells, B1-Cells, and Alternatively Activated Macrophages. Biomedicines 2019, 7, 85. [CrossRef]

92. Schierack, P.; Lucius, R.; Sonnenburg, B.; Schilling, K.; Hartmann, S. Parasite-specific immunomodulatory functions of filarial cystatin. Infect. Immun. 2003, 71, 2422-2429. [CrossRef]

93. Schnoeller, C.; Rausch, S.; Pillai, S.; Avagyan, A.; Wittig, B.M.; Loddenkemper, C.; Hamann, A.; Hamelmann, E.; Lucius, R.; Hartmann, S. A helminth immunomodulator reduces allergic and inflammatory responses by induction of IL-10-producing macrophages. J. Immunol. 2008, 180, 4265-4272. [CrossRef] [PubMed]

94. Danilowicz-Luebert, E.; Steinfelder, S.; Kuhl, A.A.; Drozdenko, G.; Lucius, R.; Worm, M.; Hamelmann, E.; Hartmann, S. A nematode immunomodulator suppresses grass pollen-specific allergic responses by controlling excessive Th2 inflammation. Int. J. Parasitol. 2013, 43, 201-210. [CrossRef] [PubMed]

95. Whelan, R.A.; Rausch, S.; Ebner, F.; Gunzel, D.; Richter, J.F.; Hering, N.A.; Schulzke, J.D.; Kuhl, A.A.; Keles, A.; Janczyk, P.; et al. A transgenic probiotic secreting a parasite immunomodulator for site-directed treatment of gut inflammation. Mol. Ther. 2014, 22, 1730-1740. [CrossRef] [PubMed]

96. Ziegler, T.; Rausch, S.; Steinfelder, S.; Klotz, C.; Hepworth, M.R.; Kuhl, A.A.; Burda, P.C.; Lucius, R.; Hartmann, S. A novel regulatory macrophage induced by a helminth molecule instructs IL-10 in CD4+ T cells and protects against mucosal inflammation. J. Immunol. 2015, 194, 1555-1564. [CrossRef] [PubMed]

97. Yadav, R.S.; Khatri, V.; Amdare, N.; Goswami, K.; Shivkumar, V.B.; Gangane, N.; Reddy, M.V. Immuno-Modulatory Effect and Therapeutic Potential of Brugia malayi Cystatin in Experimentally Induced Arthritis. Indian J. Clin. Biochem. 2016, 31, 203-208. [CrossRef] 
98. Yadav, R.S.P.; Khatri, V.; Amdare, N.; Goswami, K.; Shivkumar, V.B.; Gangane, N.; Reddy, M.V.R. Evaluation of preventive effect of Brugia malayi recombinant cystatin on mBSA-induced experimental arthritis. Indian J. Exp. Biol. 2017, 55, 5.

99. Togre, N.; Khatri, V.; Nakhale, M.; Bhoj, P.; Goswami, K.; Tarnekar, A.; Patil, M.; Kumar, S. Exploration of immune modulation by combination of filarial proteins against DSS induced acute colitis in mouse model. Rom. Arch. Microbiol. Immunol. 2018, 77, 15.

100. Togre, N.; Bhoj, P.; Goswami, K.; Tarnekar, A.; Patil, M.; Shende, M. Human filarial proteins attenuate chronic colitis in an experimental mouse model. Parasite Immunol. 2018, 40. [CrossRef]

101. Liu, F.; Cheng, W.; Pappoe, F.; Hu, X.; Wen, H.; Luo, Q.; Wang, S.; Deng, F.; Xie, Y.; Xu, Y.; et al. Schistosoma japonicum cystatin attenuates murine collagen-induced arthritis. Parasitol. Res. 2016, 115, 3795-3806. [CrossRef]

102. Wang, S.; Xie, Y.; Yang, X.; Wang, X.; Yan, K.; Zhong, Z.; Wang, X.; Xu, Y.; Zhang, Y.; Liu, F.; et al. Therapeutic potential of recombinant cystatin from Schistosoma japonicum in TNBS-induced experimental colitis of mice. Parasites Vectors 2016, 9, 6. [CrossRef]

103. Li, H.; Wang, S.; Zhan, B.; He, W.; Chu, L.; Qiu, D.; Li, N.; Wan, Y.; Zhang, H.; Chen, X.; et al. Therapeutic effect of Schistosoma japonicum cystatin on bacterial sepsis in mice. Parasites Vectors 2017, 10, 222. [CrossRef]

104. Yan, K.; Wang, B.; Zhou, H.; Luo, Q.; Shen, J.; Xu, Y.; Zhong, Z. Amelioration of type 1 diabetes by recombinant fructose-1,6-bisphosphate aldolase and cystatin derived from Schistosoma japonicum in a murine model. Parasitol. Res. 2020, 119, 203-214. [CrossRef] [PubMed]

105. Coronado, S.; Barrios, L.; Zakzuk, J.; Regino, R.; Ahumada, V.; Franco, L.; Ocampo, Y.; Caraballo, L. A recombinant cystatin from Ascaris lumbricoides attenuates inflammation of DSS-induced colitis. Parasite Immunol. 2017, 39. [CrossRef]

106. Jang, S.W.; Cho, M.K.; Park, M.K.; Kang, S.A.; Na, B.K.; Ahn, S.C.; Kim, D.H.; Yu, H.S. Parasitic helminth cystatin inhibits DSS-induced intestinal inflammation via IL-10(+)F4/80(+) macrophage recruitment. Korean J. Parasitol. 2011, 49, 245-254. [CrossRef] [PubMed]

107. Pawankar, R. Allergic diseases and asthma: A global public health concern and a call to action. World Allergy Organ. J. 2014, 7, 12. [CrossRef] [PubMed]

108. Akdis, C.A.; Akdis, M. Mechanisms of allergen-specific immunotherapy. J. Allergy Clin. Immunol. 2011, 127, 18-27. [CrossRef]

109. Boring, M.A.; Hootman, J.M.; Liu, Y.; Theis, K.A.; Murphy, L.B.; Barbour, K.E.; Helmick, C.G.; Brady, T.J.; Croft, J.B. Prevalence of Arthritis and Arthritis-Attributable Activity Limitation by Urban-Rural County Classification-United States, 2015. MMWR Morb. Mortal. Wkly. Rep. 2017, 66, 527-532. [CrossRef]

110. Tsukasaki, M.; Takayanagi, H. Osteoimmunology: Evolving concepts in bone-immune interactions in health and disease. Nat. Rev. Immunol. 2019, 19, 626-642. [CrossRef]

(C) 2020 by the authors. Licensee MDPI, Basel, Switzerland. This article is an open access article distributed under the terms and conditions of the Creative Commons Attribution (CC BY) license (http://creativecommons.org/licenses/by/4.0/). 